\title{
Guar root and shoot growth as affected by soil compaction ${ }^{1}$
}

Doglas Bassegio ${ }^{2}$, Marcos Vinicius Mansano Sarto², Ciro Antonio Rosolem ${ }^{4}$, Jaqueline Rocha Wobeto Sarto

\section{ABSTRACT}

Guar (Cyamopsis tetragonoloba L.) is commonly grown in arid lands, because of its high drought-tolerance. However, soil compaction may be a limiting factor to its growth. This study aimed to evaluate the guar growth, according to the soil penetration resistance $(0.20 \mathrm{MPa}, 0.33 \mathrm{MPa}, 0.50 \mathrm{MPa}$, $0.93 \mathrm{MPa}$ and $1.77 \mathrm{MPa}$, in a layer with depth between $0.15 \mathrm{~m}$ and $0.20 \mathrm{~m}$ ), in a Rhodic Acrudox soil. The shoot and root dry mass, root length by the $\mathrm{Q}_{1 / 2}$ index (mechanical soil penetration resistance in which the root growth is reduced by $50 \%$ ) and root diameter were evaluated. The impairment of the guar shoot growth begins when the penetration resistance is greater than around $1 \mathrm{MPa}$. The soil compaction alters the distribution of guar roots in the soil profile, concentrating them in the $0.15 \mathrm{~m}$ layer, but it does not prevent roots from penetrating this layer and developing in depth. The root diameter increases in the compacted layer. A soil penetration resistance of up to $1.77 \mathrm{MPa}$ does not influence the root length density below the compacted layer, as well as the total root length density of guar. Although the guar $\mathrm{Q}_{1 / 2}$ index is greater than 1.58 , the shoot and root dry mass are impaired.

KEYWORDS: Cyamopsis tetragonoloba L.; soil penetration resistance; root elongation.

\section{INTRODUCTION}

There is a need for the introduction of plants with industrial potential that are also tolerant to the abiotic stresses characteristic of tropical climates. In this context, guar (Cyamopsis tetragonoloba L.), a legume of the Fabaceae family, may be an alternative in crop rotation systems (Gresta et al. 2013, Shekhawat et al. 2016), given its wide industrial

\section{RESUMO}

\section{Crescimento de raiz e parte}

aérea de guar afetados pela compactação do solo

O guar (Cyamopsis tetragonoloba L.) é comumente cultivado em terras áridas, por ser altamente tolerante à seca. No entanto, a compactação do solo pode ser um fator limitante ao seu cultivo. Objetivou-se avaliar o crescimento de guar, em função da resistência do solo à penetração $(0,20 \mathrm{Mpa} ; 0,33 \mathrm{Mpa} ; 0,50 \mathrm{Mpa}$; $0,93 \mathrm{Mpa}$; e 1,77 Mpa, em camada com profundidade entre $0,15 \mathrm{~m}$ e $0,20 \mathrm{~m}$ ), em Latossolo Vermelho Distroférrico. Avaliaram-se a massa seca da parte aérea e raiz, o comprimento radicular a partir do índice $\mathrm{Q}_{1 / 2}$ (resistência mecânica do solo à penetração na qual o crescimento radicular é reduzido à metade) e o diâmetro radicular. $\mathrm{O}$ crescimento da parte aérea de guar começa a ser prejudicado por resistência superior a cerca de $1 \mathrm{MPa}$. A compactação do solo altera a distribuição das raízes de guar no perfil do solo, concentrandoas na camada de $0,15 \mathrm{~m}$, mas não impede que as raízes penetrem nessa camada e se desenvolvam em profundidade. $\mathrm{O}$ diâmetro de raiz aumenta na camada compactada. A resistência à penetração no solo de até 1,77 MPa não influencia na densidade de comprimento radicular abaixo da camada compactada, bem como na densidade de comprimento radicular total de guar. Embora o índice $Q_{1 / 2}$ de guar seja superior a 1,58, a massa seca da parte aérea e da raiz são prejudicadas.

PALAVRAS-CHAVE: Cyamopsis tetragonoloba L.; resistência do solo à penetração; elongação radicular.

application (Kumar et al. 2017) and drought tolerance (Kumawat \& Dayanand 2015). Furthermore, guar has the potential to improve soil fertility, since it can fix atmospheric nitrogen (Brar \& Singh 2017).

Guar is cultivated primarily as a commercial crop in India, which globally ranks the highest position, in terms of guar production (75-82\%), followed by Pakistan (10-12 \%) (Kumar et al. 2017). However, the abrupt and unexpected increase in

1. Manuscript received in Mar./2018 and accepted for publication in Jun./2018 (http://dx.doi.org/10.1590/1983-40632018v4852189).

2. Universidade Estadual do Oeste do Paraná, Cascavel, PR, Brasil.E-mail: doglas.bassegio@gmail.com.

3. Kansas State University, Department of Agronomy, Manhattan, KS, United States of America. E-mail: marcos.sarto28@gmail.com.

4. Universidade Estadual Paulista "Júlio de Mesquita Filho", Faculdade de Ciências Agronômicas, Departamento de Agricultura, Botucatu, SP, Brasil.E-mail: rosolem@fca.unesp.br.

5. Universidade Estadual Paulista “Júlio de Mesquita Filho", Faculdade de Medicina Veterinária e Zootecnia, Botucatu, SP, Brasil.E-mail: jaquelinerwsarto@gmail.com. 
the demand for guar gum in recent years has led to cultivation spreading to regions with better climate and fertility conditions (Kumar et al. 2016), and countries such as Australia and the USA have begun to cultivate guar (Boghara et al. 2016). Brazil is one of the largest importers of guar gum, only slightly lower than Australia and Austria (India 2014), where the product is valued for its benefits and food properties, as well as its industrial potential: guar is a valuable industrial crop because of the high galactomannan content in its endosperm (Gresta et al. 2018).

Despite its importance, guar yield remains low and, therefore, needs to be increased (Kumar et al. 2017). Although guar is a drought-tolerant species, its yield may be affected by soil compaction. Compacted layers increase the soil resistance to root penetration, restricting the growth depth, thus hindering the access to groundwater. However, species differ in their ability to overcome compacted soil layers, due to differences in soil pore size and root diameter (Rose et al. 2009).

Several studies have been conducted using compacted polyvinyl chloride (PVC) rings to determine the tolerance of annual species to soil compaction (Rosolem et al. 2002, Castagnara et al. 2013, Falkoski Filho et al. 2013, Silva et al. 2014, Sarto et al. 2018). However, little is known about either the agricultural management of guar (Gresta et al. 2013) or its sensitivity to soil compaction, although Bowen (1981) indicates that guar is a plant capable of penetrating a compressed zone and forming biochannels, providing a way for new roots to grow through the compacted zone.

Given the limited amount of scientific information available, we hypothesized that, as well as being tolerant to drought, guar can also develop in compacted soils. Thus, this study aimed to evaluate the root and shoot growth of guar under soil compaction levels.

\section{MATERIAL AND METHODS}

The experiment was carried out in a greenhouse of the Universidade Estadual Paulista, in Botucatu, São Paulo state, Brazil, in November 2015. Soil was collected at a depth of 0.00-0.20 m, from a Latossolo Vermelho distroférrico (Santos et al. 2013), or Rhodic Acrudox (USA 2010), and sieved through a $4 \mathrm{~mm}$ mesh. The chemical analysis was conducted based on the recommendations of Raij et al. (2001), with the following results: $\mathrm{CaCl}_{2}=0.01 \mathrm{~mol} \mathrm{~L}^{-1} ; \mathrm{pH}=5.1$; organic matter $=27 \mathrm{~g} \mathrm{dm}^{-3} ; \mathrm{P}$ resin $=34 \mathrm{mg} \mathrm{dm}^{-3}$; $\mathrm{K}^{+}=7 \mathrm{mmol}_{\mathrm{c}} \mathrm{dm}^{-3} ; \mathrm{Ca}^{2+}=48 \mathrm{mmol}_{\mathrm{c}} \mathrm{dm}^{-3} ; \mathrm{Mg}^{2+}=$ $17 \mathrm{mmol}_{\mathrm{c}} \mathrm{dm}^{-3}$; cation exchange capacity $(\mathrm{CEC})=$ $105 \mathrm{mmol}_{\mathrm{c}} \mathrm{dm}^{-3}$; and saturation basis $=68 \%$. The soil comprised $630 \mathrm{~g} \mathrm{~kg}^{-1}$ of sand, $90 \mathrm{mg} \mathrm{kg}^{-1}$ of silt and $280 \mathrm{~g} \mathrm{~kg}^{-1}$ of clay (Embrapa 1997). The natural density of the soil was around $1.2 \mathrm{Mg} \mathrm{m}^{-3}$, and the maximum soil water retention capacity, assessed in a tension table at $-0.03 \mathrm{MPa}$, was $180 \mathrm{~g} \mathrm{~kg}^{-1}$.

The experimental design consisted of a randomized complete block, with five soil compaction levels (treatments), corresponding to the density values of $1.2 \mathrm{Mg} \mathrm{m}^{-3}, 1.3 \mathrm{Mg} \mathrm{m}^{-3}, 1.4 \mathrm{Mg} \mathrm{m}^{-3}$, $1.5 \mathrm{Mg} \mathrm{m}^{-3}$ and $1.6 \mathrm{Mg} \mathrm{m}^{-3}$, and four replications.

The pots were assembled using overlapping PVC rings with an internal diameter of $0.10 \mathrm{~m}$. The height of the top and bottom rings was $0.15 \mathrm{~m}$, and the height of the intermediate ring, in which the compaction levels were imposed, was $0.05 \mathrm{~m}$. The total pots height was $0.35 \mathrm{~mm}$. The rings were attached together with plastic tape, and a $2 \mathrm{~mm}$ screen was adapted at the bottom to function as a barrier, to avoid root growth near the wall of the ring containing the compacted soil. The edge of the tape on the intermediate ring was folded into the pot, in order to create an obstacle and avoid preferential growth along the walls. For preparing the rings containing the compacted layer, the mass required to fill the PVC ring was previously calculated and the soil was then accommodated by applying light pressure, using an iron cylinder that had the same internal diameter as the rings.

Determinations of the penetration resistance levels in the compacted layers were made with four samplings at $80 \%$ of the field capacity, using a bench penetrometer (model MA 933; Marconi, SP, Brazil). This tool has shank and conical tip diameters of $4 \mathrm{~mm}$ and $6 \mathrm{~mm}$, respectively, semi-angle of $30^{\circ}$ and base area of $0.126 \mathrm{~cm}^{2}$. The vertical displacement speed of the shaft was $1.0 \mathrm{~cm} \mathrm{~min}^{-1}$, to a depth of $4.0 \mathrm{~cm}$, to ensure that a layer of $3.5 \mathrm{~cm}$ depth had been crossed.

Fertilizer was applied, comprising $200 \mathrm{~kg} \mathrm{ha}^{-1}$ of $\mathrm{P}$ (single superphosphate), $240 \mathrm{~kg} \mathrm{ha}^{-1}$ of K (potassium chloride) and $200 \mathrm{~kg} \mathrm{ha}^{-1}$ of N (urea), mixed into the entire soil volume. After assembling the pots, the guar (FCA-4) was seeded, retaining two seedlings per pot, at five days after the emergence. The soil moisture was monitored on a daily basis, by maintaining it close to $80 \%$ of the field capacity, 
using weight measurements and water application on both the surface and subsurface, according to the methodologies of Rosolem et al. (2002) and Falkoski Filho et al. (2013). At 25 days after emergence (Rosolem et al. 2002), the pots were dismantled and the roots collected from each layer (top, compacted and bottom).

Images of the roots were obtained by scanning in an optical reading scanner (resolution of $300 \mathrm{dpi}$ ) and then analyzed using the WinRHIZO software, version 3.8-b (Regent Instrument Inc., Quebec, Canada). The root length density and average root diameter were assessed. All roots were analyzed.

In the compacted soil layer, the $\mathrm{Q}_{1 / 2}$ index (value for mechanical soil penetration resistance in which the root growth is reduced by $50 \%$, i.e., the amount of soil penetration resistance, measured with a penetrometer, in which the root growth is reduced to half of the maximum) was determined using the adjusted model for root length density in the compacted layer (Dexter 1987). Subsequently, the roots were dried in an oven at $60^{\circ} \mathrm{C}$, for $48 \mathrm{~h}$, and their individual weight determined (total dry matter). Plant shoots were also dried in an oven at $60{ }^{\circ} \mathrm{C}$, for $72 \mathrm{~h}$.

Data were initially checked to the assumptions of normal distribution and homogeneity of variances, respectively by the Kolmogorov-Smirnov and Levene tests. Thus, regression analyses were performed and equations with a significance level of $5 \%$ $(\mathrm{p} \leq 0.05)$, according to the F-test, were considered.

\section{RESULTS AND DISCUSSION}

The soil penetration resistances in the compacted layer were $0.20 \mathrm{MPa}, 0.33 \mathrm{MPa}, 0.50 \mathrm{MPa}, 0.93 \mathrm{MPa}$ and $1.77 \mathrm{MPa}$, respectively for the densities of $1.2 \mathrm{mg} \mathrm{m}^{-3}, 1.3 \mathrm{mg} \mathrm{m}^{-3}, 1.4 \mathrm{mg} \mathrm{m}^{-3}, 1.5 \mathrm{mg} \mathrm{m}^{-3}$ and $1.6 \mathrm{mg} \mathrm{m}^{-3}$ (Figure 1), at a depth of $0.15-0.20 \mathrm{~m}$. This finding was in agreement with the literature, as values higher than $2 \mathrm{MPa}$ generally prevent the development of most crops (Baio et al. 2017). The values in the present study were close to those reported by Foloni et al. (2006) for a clay-textured Red Nitosol (0.26$1.98 \mathrm{MPa}$ ), Sarto et al. (2018) for a Dystroferric Red Latosol (0.20-1.77 MPa) and Falkoski Filho et al. (2013) for a Dystrophic Red Nitosol (0.41-1.92 MPa), which are soils with similar textures.

The root and shoot dry matter yield increased by $47 \%$ and $50 \%$, respectively, when the penetration resistance was increased to $0.95 \mathrm{MPa}$ and $0.87 \mathrm{MPa}$, respectively. When the penetration resistance was higher than $0.87 \mathrm{MPa}$, the growth of roots and shoots was impaired (Figure 2). A similar behavior has been reported in studies with stubble turnips, black oat

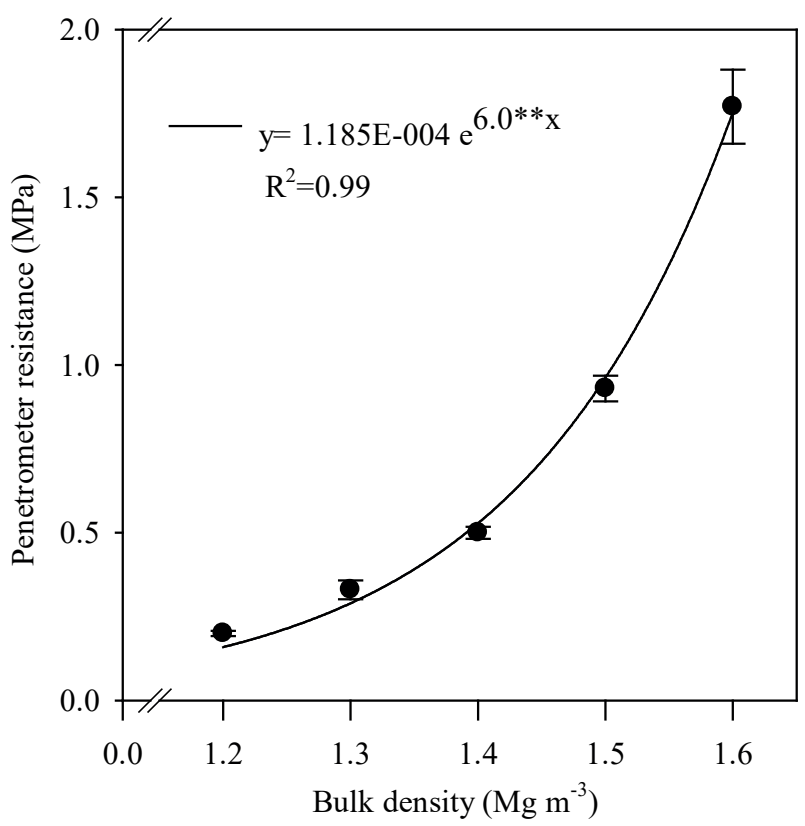

Figure 1. Penetrometer resistance in the compacted layer, as affected by soil bulk density. ** Significant at $1 \%$. Error bars indicate the standard deviation.

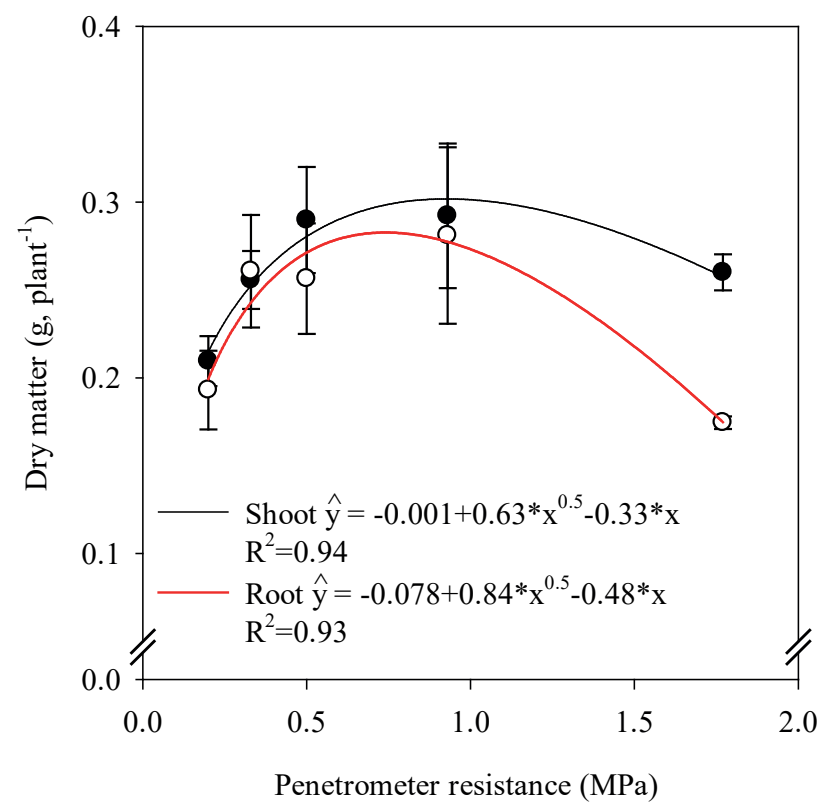

Figure 2. Shoot and total root dry matter, as affected by penetrometer resistance. ${ }^{*}$ Significant at $5 \%$. Error bars indicate the standard deviation. 
and white oat (0.10-1.34 MPa) (Müller et al. 2001), Stylosanthes (1.0-1.83 $\mathrm{Mg} \mathrm{m}^{-3}$ ) (Castagnara et al. 2013), cotton (0.41-1.92 MPa) (Falkoski Filho et al. 2013), pearl millet (1.28-1.74 $\mathrm{Mg} \mathrm{m}^{-3}$ ) (Guimarães et al. 2013) and cover crops (1.10-1.90 $\left.\mathrm{Mg} \mathrm{m}^{-3}\right)$ (Lima et al. 2015). The dry matter production of safflower shoots increased when the penetration resistance level was increased to $0.79 \mathrm{MPa}$ and $0.93 \mathrm{MPa}$, respectively for the IMA-2106 and IMA4904 genotypes (Sarto et al. 2018).

This response occurs because any slight increase in density, in levels of low penetration resistance in loose soil, results in an increased contact between the soil and roots, therefore enhancing the conditions for water and nutrient absorption, without interfering with growth (Müller et al. 2001). According to Silva et al. (2006), the observed effects of compaction on shoot growth may be due to the replacement of the surface water supply by subsurface irrigation, as verified by the authors for corn, cotton and Brachiaria. This enables to analyze the effect of the compacted layer on plant development and growth, according to water dynamics. Thus, in order to avoid the effects of soil compaction on the growth of plant shoots in the experimental pots, suitable water and nutrient conditions must be maintained (Chen et al. 2014).

Although the increased compaction caused significant effects on the root and shoot dry matter yield, modifying the distribution of the radicle system along its profile, it did not interfere in the total length of roots (Figure 3). However, the root length along the soil profile showed that increasing the soil density in the compacted layer promoted an increase in root length density in the top layer (Figure 4A). This is because the soil compaction hindered the root growth in the compacted layer, leading to an increased growth, or confinement, in the top layer (Silva et al. 2014). This increase in the top layer may have occurred because of lateral root proliferation, due to an increase in the ethylene production by stressed roots (Geisler-Lee et al. 2010). The soil penetration resistance did not influence the root length density below the compacted layer. The root length below the compacted layer varied randomly, and did not maintain proportionality with the soil mechanical impedance levels used in the experiment (Figure 4C).

In this study, according to the adjusted equation (Figure $4 \mathrm{~B}$ ), a $\mathrm{Q}_{1 / 2}$ value above $1.58 \mathrm{MPa}$ was observed, which was higher than those obtained by Rosolem et al. (2002) for Pennisetum glaucum (0.73 MPa), Sorghum bicolor (0.30 MPa), Crotalaria juncea $(0.97 \mathrm{MPa})$ and Helianthus annuus $(0.86 \mathrm{MPa})$, and by Foloni et al. (2006) for Glycine $\max (1.22 \mathrm{MPa})$ and Dolichos lablab (1.46 MPa), and close to the values found by Sarto et al. (2018) for Carthamus tinctorius L. (1.77 MPa and $1.55 \mathrm{MPa}$, respectively for the IMA-2106 and IMA-4904 genotypes). Thus, the characterization of soil mechanical impedance, in which $50 \%$ of the root growth is impaired $\left(\mathrm{Q}_{1 / 2}\right.$ index), is a way of measuring the sensitivity of a given species to compaction. However, the quantity of roots penetrating a certain volume of compacted soil defines the potential of a plant to form biopores and improve the soil physical conditions for subsequent crops (Silva et al. 2006). Dexter (1987), in a study on Pisum sativum, and Materechera et al. (1992), in a study on Lupinus angustifolius and Vicia faba (which are also drought-tolerant leguminous plants from the Fabaceae family), reported that these plants showed the largest tolerance to high compaction $(4.2 \mathrm{MPa})$, among more than 20 studied species.

The root diameter in the top layer (Figure 5A) decreased by $11 \%$. The compacted soil in the layer below, as well as difficulties in penetration, may have increased the proliferation of fine lateral roots. In the

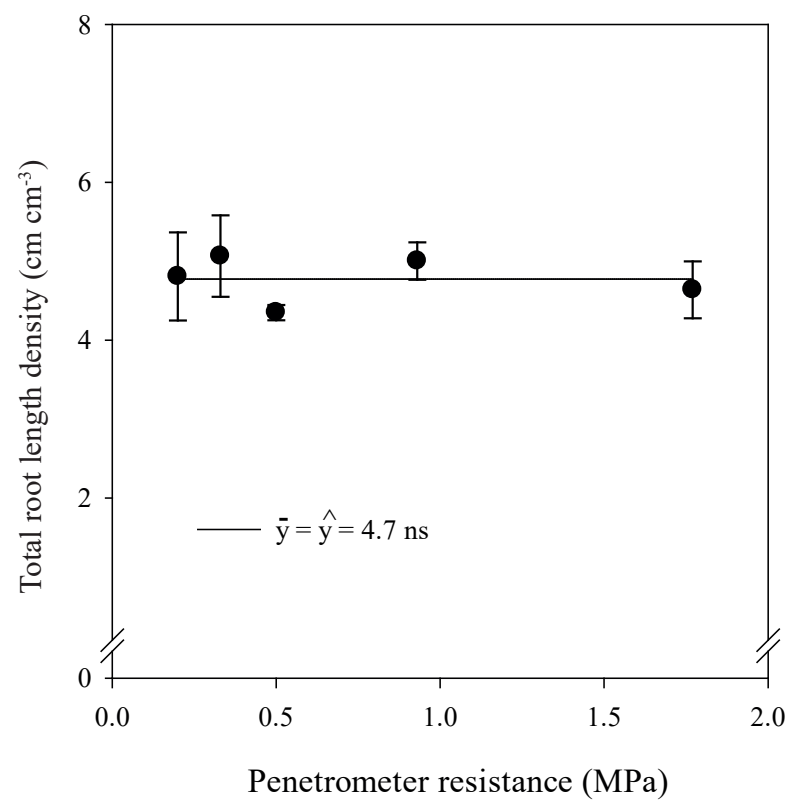

Figure 3. Total root length density, as affected by penetrometer resistance. ns: not significant. Error bars indicate the standard deviation. 


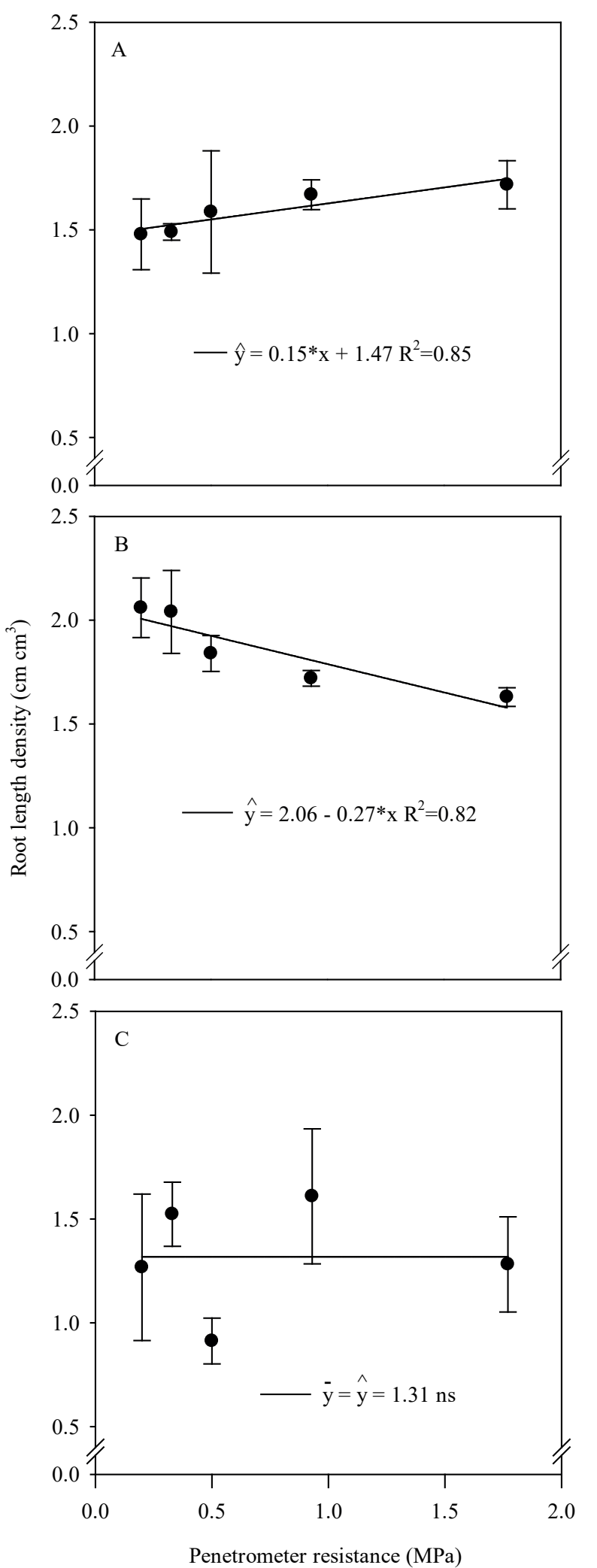

Figure 4. Guar root length density in the upper layer (A), compacted soil layer (B) and below (C) the compacted layer, as affected by penetrometer resistance. * Significant at $5 \%$; ns: not significant. Error bars indicate the standard deviation.
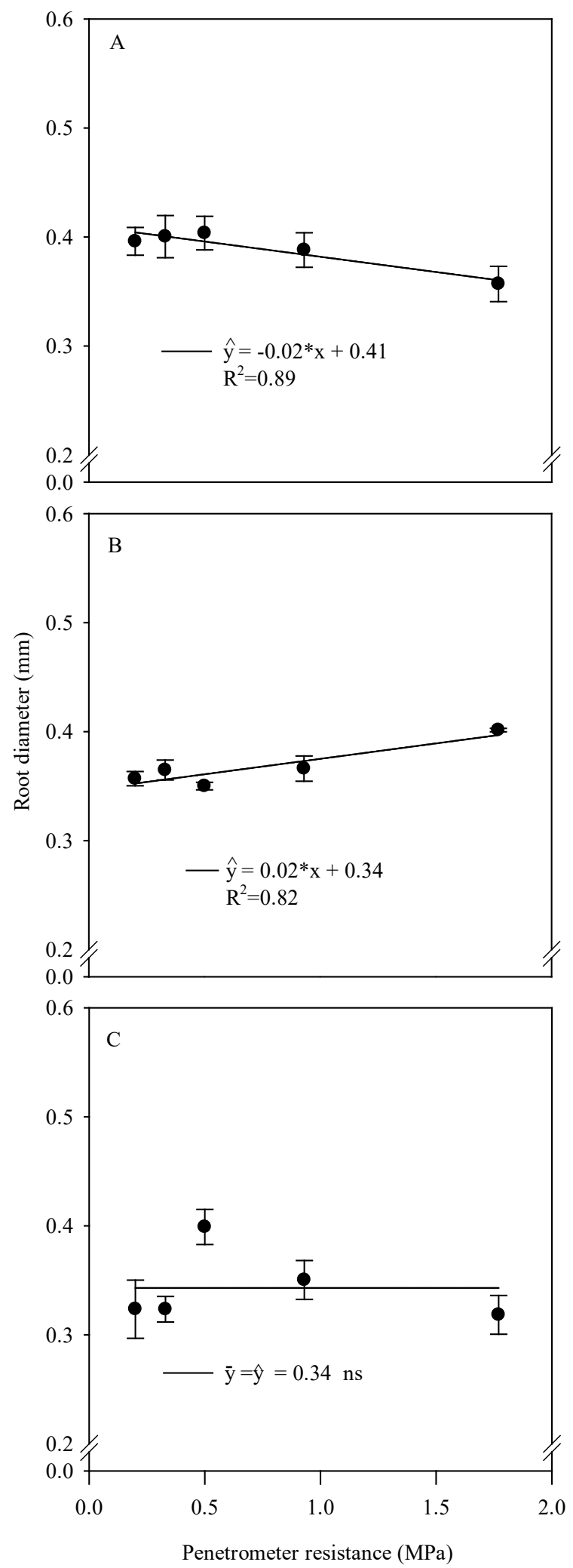

Figure 5. Guar root diameter in the upper layer (A), compacted soil layer (B) and below (C) the compacted layer, as affected by penetrometer resistance. * Significant at $5 \%$; ns: not significant. Error bars indicate the standard deviation. 
layer below the compacted soil layer (Figure 5C), the average radicle diameter did not vary, as a function of the compaction levels. This was also observed for length density.

In the compacted soil layer (Figure 5B), the average guar radicle diameter increased by $14 \%$, according to the soil penetration mechanical resistance. Sarto et al. (2018) have also observed that the root diameter of Carthamus tinctorius L. (IMA-2106 genotype) increased in the compacted layer, with an increased mechanical penetration resistance. This indicates that compaction promotes root thickening, because of morphophysiological changes in the radicle system after entering the compacted layer (Ramos et al. 2010). These results are also in agreement with the hypothesis of Russell \& Goss (1974), which state that mechanical soil resistance typically causes increases in root diameter within the compacted layer. The greater the root diameter, the greater the force exerted in the elongation process of meristem root cells for penetration, in a determined soil layer (Foloni et al. 2006). This is consistent with the results obtained under controlled conditions, in which an increase in root diameter in compacted soils was observed by Pfeifer et al. (2014) in barley and by Grzesiak et al. (2013) in triticale, as well as under field conditions in barley (Hernandez-Ramirez et al. 2014).

\section{CONCLUSIONS}

1. The impairment of guar shoot growth begins when the penetration resistance is greater than $\sim 1 \mathrm{MPa}$, at $80 \%$ of the field capacity;

2 . The guar root diameter increases in the compacted layer;

3. A soil penetration resistance below $1.77 \mathrm{MPa}$ does not influence the root length density below the compacted layer, as well as the total root length density of guar in a controlled environment and deformed soil samples. The $\mathrm{Q}_{1 / 2}$ index for guar is higher than 1.58 .

\section{ACKNOWLEDGMENTS}

We thank the Coordenação de Aperfeiçoamento de Pessoal de Nível Superior (Capes), for the grants awarded, and the Fundação de Amparo à Pesquisa do Estado de São Paulo (FAPESP), for the financial support of this research (Registry numbers: 2014/10656-3 and 2016/14323-4).

\section{REFERENCES}

BAIO, F. H. et al. Soil resistance to penetration in cotton rows and interrows. Revista Brasileira de Engenharia Agrícola e Ambiental, v. 21, n. 6, p. 433-439, 2017.

BOGHARA, M. C. et al. Genetic divergence, path analysis and molecular diversity analysis in cluster bean (Cyamopsis tetragonoloba L. Taub.). Industrial Crops and Products, v. 89, n. 11, p. 468-477, 2016.

BOWEN, H. D. Alleviating mechanical impedance. In: ARKIN, G. F.; TAYLOR, H. M. Modifying the root environment to reduce crop stress. St. Joseph: American Society of Agricultural Engineers, 1981. p. 21-57.

BRAR, S. K.; SINGH, P. Response of cluster bean (Cyamopsis tetragonoloba L. Taub.) cultivars to dual inoculation with fixing and phosphorous solubizing bacteria. Legume Research, v. 40, n. 1, p. 100-104, 2017.

CASTAGNARA, D. D. et al. Crescimento de Stylosanthes cv. Campo Grande em diferentes níveis de densidade de um Latossolo Vermelho. Revista Ciência Agronômica, v. 44, n. 2, p. 260-266, 2013.

CHEN, Y. L. et al. Root architecture alteration of narrowleafed lupin and wheat in response to soil compaction. Field Crops Research, v. 165, n. 1, p. 61-70, 2014.

DEXTER, A. R. Mechanics of root growth. Plant and Soil, v. 98 , n. 3, p. 303-312, 1987.

EMPRESA BRASILEIRA DE PESQUISA AGROPECUÁRIA (Embrapa). Centro Nacional de Pesquisa de Solos. Manual de métodos de análise de solo. 2. ed. Rio de Janeiro: Embrapa Solos, 1997.

FALKOSKI FILHO, J.; BATISTA, I.; ROSOLEM, C. A. Sensibilidade de cultivares de algodoeiro à compactação do solo. Semina: Ciências Agrárias, v. 34, n. 6, p. 36453654, 2013.

FOLONI, J. S. S.; LIMA, S. L.; BULL, L. T. Crescimento aéreo e radicular da soja e de plantas de cobertura em camadas de solo compactado. Revista Brasileira de Ciência do Solo, v. 30, n. 1, p. 48-57, 2006.

GEISLER-LEE, J.; CALDWELL, C.; GALLIE, D. R. Expression of the ethylene biosynthetic machinery in maize roots is regulated in response to hypoxia. Journal of Experimental Botany, v. 61, n. 3, p. 857-871, 2010.

GRESTA, F. et al. Effects of sowing times on seed yield, protein and galactomannans content of four varieties of guar (Cyamopsis tetragonoloba L.) in a Mediterranean environment. Industrial Crops and Products, v. 41, n. 1, p. 46-52, 2013.

GRESTA, F. et al. Morphological, biological, productive and qualitative characterization of 68 guar (Cyamopsis 
tetragonoloba (L.) Taub.) genotypes. Industrial Crops and Products, v. 114, n. 1, p. 98-107, 2018.

GRZESIAK, S. et al. Changes in root system structure, leaf water potential and gas exchange of maize and triticale seedlings affected by soil compaction. Environmental and Experimental Botany, v. 88, n. 1, p. 2-10, 2013.

GUIMARÃES, C. V. et al. Desempenho de cultivares e híbridos de milheto em solo submetido a compactação. Revista Brasileira de Engenharia Agrícola e Ambiental, v. 17, n. 11, p. 1188-1194, 2013.

HERNANDEZ-RAMIREZ, G. et al. Root responses to alterations in macroporosity and penetrability in a silt loam soil. Soil Science Society of America Journal, v. 78, n. 4, p. 1392-1403, 2014.

INDIA. National Rainfed Area Authority. Potential of rainfed guar (cluster bean): cultivation, processing and export in India. 3. ed. New Delhi: DPS Marg, 2014.

KUMAR, S. et al. Development and validation of ESTderived SSR markers and diversity analysis in cluster bean (Cyamopsis tetragonoloba). Journal of Plant Biochemistry and Biotechnology, v. 25, n. 3, p. 263-269, 2016.

KUMAR, S. et al. Role of conventional and biotechnological approaches for genetic improvement of cluster bean. Industrial Crops and Products, v. 97, n. 3, p. 639-648, 2017.

KUMAWAT, R. N.; DAYANAND, M. H. R. Effect of foliar applied urea and planting pattern on the leaf pigments and yield of cluster bean (Cyamopsis tetragonoloba L.) grown in low rainfall areas of western India. Legume Research, v. 38, n. 1, p. 96-100, 2015.

LIMA, L. B. et al. Desempenho de plantas de cobertura sob níveis de compactação em Latossolo Vermelho de Cerrado. Revista Brasileira de Engenharia Agrícola e Ambiental, v. 19, n. 11, p. 1064-1071, 2015.

MATERECHERA, S. A. et al. Influence of root diameter on the penetration of seminal roots into a compacted subsoil. Plant and Soil, v. 144, n. 2, p. 297-303, 1992.

MÜller, M. M. L.; CECCON, G.; ROSOLEM, C. A. Influência da compactação do solo em subsuperfície sobre o crescimento aéreo e radicular de plantas de adubação verde de inverno. Revista Brasileira de Ciência do Solo, v. 25, n. 3, p. 531-538, 2001.

PFEIFER, J. et al. Spring barley shows dynamic compensatory root and shoot growth responses when exposed to localised soil compaction and fertilisation. Functional Plant Biology, v. 41, n. 6, p. 581-597, 2014.

RAIJ, B. V. et al. Análise química para avaliação da fertilidade de solos tropicais. Campinas: Instituto Agronômico, 2001.

RAMOS, J. C. et al. Morphological characteristics of soybean root apexes as indicators of soil compaction. Scientia Agricola, v. 67, n. 6, p. 707-712, 2010.

ROSE, T. J. et al. Crop species differ in root plasticity response to localised P supply. Journal of Plant Nutrition and Soil Science, v. 172, n. 3, p. 360-368, 2009.

ROSOlEM, C. A.; FOLONI, J. S. S.; TIRITAN, C. S. Root growth and nutrient accumulation in cover crops as affected by soil compaction. Soil and Tillage Research, v. 65 , n. 1, p. 109-115, 2002.

RUSSELL, R. S.; GOSS, M. J. Physical aspects of soil fertility: the response of roots to mechanical impedance. Netherlands Journal of Agricultural Science, v. 22, n. 1, p. 305-318, 1974.

SANTOS, H. G. et al. Sistema brasileiro de classificação dos solos. 3. ed. Brasília, DF: Embrapa, 2013.

SARTO, M. V. M. et al. Safflower root and shoot growth affected by soil compaction. Bragantia, v. 77, n. 2, p. 348355,2018 .

SHEKHAWAT, K. et al. Crop establishment techniques affect productivity, sustainability, and soil health under mustard-based cropping systems of Indian semi-arid regions. Soil and Tillage Research, v. 158, n. 4, p. 137-146, 2016.

SILVA, G. J.; MAIA, J. C. S.; BIANCHINI, A. Crescimento da parte aérea de plantas cultivadas em vaso, submetidas à irrigação subsuperficial e a diferentes graus de compactação de um Latossolo Vermelho-Escuro Distrófico. Revista Brasileira de Ciência do Solo, v. 30, n. 1, p. 31-40, 2006.

USA. Soil Survey Staff. Keys to soil taxonomy. 11. ed. Washington, DC: USDA-Natural Resources Conservation Service, 2010. 